\title{
Details of the Contributors
}

Lihi Habas is an archaeologist and art historian, teaching at the Institute of Archaeology of the Hebrew University of Jerusalem on various subjects related to the archaeology and art of the ancient, classical, Roman and Byzantine eras. Dr. Habas researches the inter-relationships between architecture, mosaics, furnishings, and ceremonial objects in the Byzantine Empire in general, with particular emphasis on the Holy Land. She researches and publishes findings from archaeological sites in Israel such as the churches of Khirbet ed-Deir, Mt. Berenice, Tel Bet Shean, Gan Yavne, Nahal Qidron, Jerusalem, Oẓem, Hazor-Ashdod, Ostrakine in northern Sinai, and many more. She also publishes minor art findings from archaeological sites and museums in Israel. She occasionally curates exhibitions on archaeological themes, as well as modern art and contemporary art, and also serves as advisor for exhibitions.

Simha Goldin is a Professor in the Department of Jewish History at Tel Aviv University, where he also serves as Director of the Goldstein-Goren Diaspora Research Center. He is a social historian whose work primarily focuses on the Jews of Ashkenaz during the Middle Ages. His research examines societal constructs like community, neighborhood, conversion, and the status of women, drawing on a broad range of methodologies and sources to provide greater understanding of the daily lives of medieval Jews and their relationships with the Christian societies among which they dwelt. Prof. Goldin's book on conversion, entitled Apostasy and Jewish Identity in High Middle Ages Northern Europe: Are You Still My Brother?, was published by Manchester University Press.

Ephraim Kanarfogel is the E. Billi Ivry University Professor of Jewish History, Literature and Law at Yeshiva University's Bernard Revel Graduate School of Jewish Studies. He has authored or edited eight books and published ninety articles and reviews. His most recent book, The Intellectual History and Rabbinic Culture of Medieval Ashkenaz, won the Goldstein-Goren International Book Award and the Jordan Schnitzer Book Prize from the Association of Jewish Studies. His forthcoming book, Brothers from Afar: Rabbinic Approaches to Apostasy and Reversion in Medieval Europe, will be published by Wayne State University Press in 2019.

Joseph Isaac Lifshitz is a research associate at the Goldstein-Goren Diaspora Research Center at Tel Aviv University and a senior lecturer at Shalem College. His books include: Rabbi Meir of Rothenburg and the Foundation of Jewish Political Thought and One God, Many Images: Dialectical Thought in Hasidei Ashkenaz.

Jean Baumgarten is a director of research emeritus at the Centre de recherches historiques (CRH), Centre National de la Recherche scientifique (CNRS-EHESS, Paris). He wrote articles and books on the Old Yiddish literature, the cultural history of the Ashkenazi world, the history of the Jewish book and the Hasidim. Latest publications: Le Petit monde: le corps humain dans les textes de la tradition juive, de la Bible aux Lumières, Paris, Albin Michel, 2017; La Légende de Yosef della Reina, activiste messianique, Paris, Editions de l'éclat, 2018. He is currently working on an edition of the Minhagim (Venice, 1593). 
Naomi Feuchtwanger-Sarig is an Adjunct Assistant Professor at Ono Academic College, Jerusalem and Senior Fellow at the Research Centre "Dynamics of Jewish Ritual Practices in Pluralistic Contexts from Antiquity to the Present" of the Max-Weber-Kolleg für kultur- und sozialwissenschaftliche Studien, Universität Erfurt. Her main fields of interest are Jewish material and visual culture, as well as the study of Christian theologian and Hebraist writings on Jewish rites and rituals that shed light on ritual and ceremonial objects, and synagogue architecture and furnishings. She is the author of numerous studies on Jewish art and visual culture. Her book, Thy Father's Instruction: Reading the Nuremberg Miscellany as Jewish Cultural History, is forthcoming, and she is currently working on the Invention of a Textual and Visual Printed Tradition: The Minhogim Bukh by Shimeon haLevi Günzburg (Venice: Giovanni di Gara, 1593), in collaboration with Jean Baumgarten of the CNRS-EHESS, Paris.

Noga BarOr-Bing graduated with honors from Hebrew University's distinguished Revivim program and received her PhD in Jewish Thought from Ben Gurion University. She specializes in modern Hasidism and gender, researching the many changes within ultra-orthodox communities. She teaches at Hebrew University, the Kerem Teachers Seminary in David Yellin College and the Hartman Institute. Today Dr. BarOr-Bing is a staff member of the Mandel Institute's program for ultra-orthodox women.

Michael J. Broyde is a Professor of Law at Emory University and Projects Director of its Center for the Study of Law and Religion. In the 2018-2019 academic year he is a visiting professor at Hebrew University School of Law as a Fulbright Senior Scholar.

Ira Bedzow is the Director of the Biomedical Ethics and Humanities Program at New York Medical College and Senior Scholar at the Aspen Center for Social Values. He is the author of numerous books, articles, and chapters on ethics, law, and social values.

Together in 2014, Broyde and Bedzow wrote The Codification of Jewish Law and an Introduction to the Jurisprudence of the Mishna Berura (Academic Studies Press).

David M. Bunis (PhD, Columbia University, 1981; Yitzhak Ben-Zvi Prize, 2006; EMET Prize, 2013; Académico Correspondiente Extranjero, Real Academia Española, 2015) is a professor in the Department of Linguistics and the Center for Jewish Languages and Literatures, Hebrew University of Jerusalem, and heads its program in Judezmo (or Ladino) studies. He is also an advisor to the Israel National Authority for Ladino Language and Culture. He is the author of A Lexicon of the Hebrew and Aramaic Elements in Modern Judezmo (Jerusalem, 1993), The Judezmo Language (in Hebrew, Jerusalem, 1999), Voices from Jewish Salonika (Jerusalem-Salonika, 1999), and numerous articles on the Judezmo language and its literature and on Jewish languages as a field of scholarly inquiry. He is the editor of Languages and Literatures of Sephardic and Oriental Jews (Jerusalem, 2009); and co-editor of Massorot, a Hebrew-language journal devoted to the study of Jewish language traditions.

Amy Weiss is the Director of the Center for Holocaust and Genocide Education at the College of Saint Elizabeth. Her research and publications focus on the intersections of American Jewish history, Israel Studies, and Jewish-Christian relations, including her current book project on Jewish-Protestant interfaith alignments and Israel. She received her PhD in Hebrew \& Judaic Studies and History from New York University. 
Ya'acov Sarig is a lecturer in the Department of Hebrew Literature at the Academic College of Education Al-Qasemi, Baqa al-Gharbiyye and the Open University, Ra'anana. His main fields of research are Jewish Yemenite folktales and Scandinavian folk literature. Dr. Sarig is the author of the book The Scandinavian Mythology, which deals with the pagan world, particularly the customs and beliefs in the Pre-Christian era in Scandinavia. His second book, Icelandic Sagas, is in the final stages of preparation. It describes the development of the Icelandic society and culture. It will include translations of sagas from Icelandic into Hebrew.

Michael A. Meyer is Adolph S. Ochs Professor of Jewish History emeritus at Hebrew Union College - Jewish Institute of Religion in Cincinnati, Ohio. He is the author, among other works, of The Origins of the Modern Jew, Response to Modernity: A History of the Reform Movement in Judaism, and Judaism within Modernity, and is the editor of German Jewish History in Modern Times (all four of these also in Hebrew), of Ideas of Jewish History, and of Volume 6 of Leo Baeck Werke. He has served as president of the Association for Jewish Studies and as international president of the Leo Baeck Institute.

Aviad Hacohen is president of the Academic Center of Law and Science and former Dean of its Law School, and Senior Research Fellow at the Van-Leer Institute, Jerusalem. In the past he was an Adjunct Professor at the Faculties of Law at Hebrew University, Jerusalem and at Bar-Ilan University. After graduating from Yeshivat Har Etzion and Yeshivat HaKotel, he received his LL.B, MA (cum laude) and PhD (magna cum laude) from the Hebrew University. Prof. Hacohen is a member of the committee on legal terms at the Academy of the Hebrew Language, founded Mosaica - the Institute for the Study of Religion, Society and State, and served as the chief editor of the official Israeli Supreme Court decisions. He has also edited and written numerous books and articles, among them: "The Tears of the Oppressed" - An Examination of the Agunah ("Chained Women") Problem (New York, 2004); Parshiyot v'Mishpatim (Tel Aviv, 2011), a collection of some of his articles, including chapters on human rights, criminal law and civil law and their relation to Jewish law, was published; entries regarding human rights in the new edition of the Encyclopedia Judaica. 
